\title{
Nonindustrial Family Forest Landowners' Stated Willingness-to-Participate in Forest Cooperatives in Southern China
}

\author{
Lifei Yang, ${ }^{1}$ Yali Wen, ${ }^{1}$ and Francisco X. Aguilar ${ }^{2}$ \\ ${ }^{1}$ School of Economics and Management, Beijing Forestry University, Beijing 100083, China \\ ${ }^{2}$ Department of Forestry, University of Missouri, Columbia, MO 65211, USA
}

Correspondence should be addressed to Francisco X. Aguilar; aguilarf@missouri.edu

Received 26 January 2013; Accepted 20 March 2013

Academic Editor: Piermaria Corona

Copyright (c) 2013 Lifei Yang et al. This is an open access article distributed under the Creative Commons Attribution License, which permits unrestricted use, distribution, and reproduction in any medium, provided the original work is properly cited.

\begin{abstract}
Forest landowner cooperatives have emerged as a formal institution capable of fostering professional forest management. There are many reasons to motivate participation in forest cooperatives. For instance, cooperatives could ease nonindustrial family forest landowners (NIFFLs) access to financial assistance and enhance market entrance opportunities. In China, various forms of forest cooperatives supported by government agencies are developing rapidly in an effort to facilitate forest management at a large scale. However, the development of forest cooperatives is still in its early stages. An understanding of NIFFLs' attitudes towards the development of cooperatives is instrumental for crafting policies and organizational structures that motivate landowners' participation. Three hundred and ten NIFFLs from Fujian and Jiangxi provinces in Southern China were interviewed to elicit their attitudes and willingness-to-participate in forest cooperatives. Logistic regression was used to evaluate landowner, household, forest resource, and institutional factors associated with NIFFLs' stated decision to participate in a forest cooperative. Results show that NIFFLs' stated willingness-to-participate in forest cooperatives was associated with demographic characteristics like education, forest-related income, size of forestland, and attitudes toward land tenure reform and cooperatives. This paper outlines suggestions on how to further develop forest cooperatives in Southern China.
\end{abstract}

\section{Introduction}

The Chinese central government has promoted a collective forestland reform since the 1980s in an effort to improve productivity, fight rural poverty, and raise living standards [1-3]. The term "collective forest tenure reform" refers to a public policy where forest property rights are reallocated from collectives to individual households with, among others, the objective to help individual households increase private ownership and forest management. The reform is deemed an important step towards shifting land ownership to the private sector [4]. Intrinsic to the land tenure reform, central and local governments have followed with the reallocation of tenure rights of forests to individuals $[5,6]$.

China's land tenure system has significantly changed the ownership structure in rural areas. The central government first targeted agricultural lands in 1978 and implement eda household-level production responsibility system [7]. Nearly
98\% of collectively-owned agricultural land had become part of household responsibility system land by 1983 [8]. Similar to the agricultural sector, a system of householdlevel production responsibility system has been implemented in forest lands, primarily in Southern China [7]. This has been conducted by distributing forestland on the basis of the number of people in each household. In turn, households can transfer forestland through contractual forms to other households or forest enterprises. However, the contracts' format, length, and content are not uniform and vary by location [4]. It was the first wave of forest reforms labeled as the "three fixes" after several challenges that halted the wider tenure reform in the forest sector: unclear collective property rights, unreasonable benefit allocation, and irregular property rights transformation [9]. Based on the Decision to Accelerate Forest Sector Development [10], issued by the central government of China, the State Forestry Administration selected Fujian, Jiangxi, Liaoning, and Zhejiang province, 
as pilot projects for the implementation of collective forest tenure reforms in 2004 . This policy aimed to make property rights clearer, alleviate landowners' tax burdens, facilitate for flexible management, and streamline the transfer of tenure rights [5]. By giving rights to households, henceforth called "nonindustrial family forest landowners," NIFFLs were allowed to manage their forestland to generate revenues. As of 2010, China has accomplished the main tasks of the forest land tenure reform in eighteen provinces [11]. Of the 149 million ha of forestland whose collective ownership rights have been clearly established, $81.69 \%$ are owned by 68.25 million households [12].

The purpose of this study was to elicit and determine factors that affect NIFFLs' willingness-to-participate in forest cooperatives in China. Empirical research on landowners' willingness-to-participate in cooperatives is an important issue in China as the government aims to further increase enrollment. Data from field surveys were used to describe local socioeconomic conditions and understand how different demographic and forest management characteristics (e.g., landowners' age, education, income, size of labor force, size of forestland, and attitudes towards forest cooperatives and forest tenure reform) influenced stated participation in cooperatives. Specifically, the objectives for this study were to: (1) analyze the association between NIFFL demographics, forest management, and their forest resource characteristics and institutional variables with their willingness-to-participate in forest cooperatives; (2) generate information to guide wider adoption of forest cooperatives in China.

\section{Literature Review}

2.1. Forest Cooperatives and Their Functions. A cooperative is defined by the International Cooperative Alliance [13] as "an autonomous association of persons united voluntarily to meet their common economic, social, and cultural needs and aspirations through a jointly owned and democratically controlled enterprise." Another widely accepted definition is provided by the U.S. Department of Agriculture that describes it as "a user-owned, user-controlled business that distributes benefits on the basis of use" [14]. Overall, a cooperative is a form of organization created to assist in meeting a variety of the members' needs. Kittredge [15] suggests four levels of forms and degrees of cooperation: (1) information cooperation: owners exchange information, techniques, and advice and experiences; (2) equipment cooperation: equipment and machinery for harvesting are shared among landowners; (3) financial cooperation: helps members secure a better price in the market; (4) management cooperation: members coordinate forest management planning and decisions beyond individual parcels. Similarly, forest management has multiple objectives, including wood or nonwood production, wildlife habitat restoration, recreation, and ecosystem protection.

Forest cooperatives can serve multiple functions. Landowner cooperation can improve a country's ability to manage forest resources and help achieve national ecological interests $[15,16]$. Numerous reports maintain that cooperation offers various benefits to participants [13, 17, 18]. According to Rickenbach et al. [19], NIFFLs organizations can provide a mechanism for promoting and coordinating cross-boundary forest management practices and landowners can share information about marketing and policy. Among other benefits, a cooperative can increase revenues to members derived from the harvest of forest products in part by helping reduce individual supply and transaction costs through large-scale management and bulk purchasing at a lower price. Forest cooperatives can also offer several services to help members develop forest management plans and receive professional technical training and services [20]. In addition, cooperatives can provide technical training like the prevention and control of diseases and pests, forest expert training, and creation of a management plan and provide public policy training and monitoring. Moreover, NIFFLs' nonmonetary land objectives can be enhanced by planning and managing forests beyond market-based benefits that expand beyond individual property [18, 21-24].

Forest owners' cooperatives can provide important tools to achieve timber production goals. For example, in Austria there are eight regional forest cooperatives with about 54,800 members. The cooperatives offer services to members to assist with the commercialization of harvested wood and provide machinery assistance and consultation on reforestation and forest issues. These cooperatives supplied 3.34 million solid cubic meters to the market, accounting for $16 \%$ of total forest utilization in 2006 [25]. According to Hogl et al. [26], forest cooperative members in Australia spend about two months per year in their forests, and most of them view their forest primarily as a source of income and employment. Private forest owners associations thrive in Estonia, Denmark, and France and other countries. The Swedish model of cooperation in which NIFFLs have historically formed associations to grain greater market influence and negotiate improved prices with industrial purchasers of wood has widely been successful. Each member of a Swedish forest owner cooperative has one vote, regardless of property size; this model has been adapted by landowners who have indicated greater interest in non-timber benefits from their forestlands [27].

There are many types of cooperatives throughout the world that demonstrate the effectiveness of utilizing a cooperation system to achieve sound forest management. Although some of these cooperatives possess impressive track records, they may not be universally appealing to all owners [28]. The ultimate goal of forest cooperatives is to improve landowners' living conditions by raising their incomes while reducing the pressure that they exert on forest [29]. Nevertheless, this goal can be difficult to attain. For instance, local cooperatives may be unable to acquire enough financial support to expand research and education opportunities, and it might be cumbersome to achieve a well-organized system of operative rules for a cooperative $[7,30,31]$.

2.2. Forest Landowners, Cooperatives, and Forest Management Decisions. How NIFFLs make decisions about forest management has been the focus of numerous studies. 
Several of these studies have recognized a multitude of factors affecting NIFFLs management decisions [17, 32-36]. Differences in ownership objectives and management preferences have resulted in various authors proposing various NIFFL typologies according to their different land objectives. Reasons for owning land by NIFFLs include both nonmarket and monetary benefits, such as outdoor recreation, aesthetics, pollution absorption, biodiversity and wildlife habitat, privacy, timber production, production of firewood, and cultivation of other forest products [15, 22, 37-39]. In China, after the land tenure reform, numerous landowners have transferred ownership of their forestland for monetary gains. The transfer of forestland can take place between two households or between a household and a forestry enterprise through signing of a contract where households can lease the totality or part of their forestland. Lease terms range generally from thirty to one hundred years and the prices of the land use rights range from 7.5-7,500 yuan/ha, but the forestland must not be changed to other land use [40]. The market system, structure of decisions, characteristics of an individual (e.g., management experience, age, occupation, education, ability, and willingness-to-adopt new and different techniques), land resources, and institutions are among the main constraints on owners' management decisions [33].

NIFFLs' demographic characteristics seem to significantly affect their land management decisions. Greene and Blatner [41] suggested that age has a positive effect on the likelihood of forestland management for timber as does occupation, education level, and landholding area. Econometric models have been used to analyze landowners' preferences. Nagubadi et al. [42] used a probit model to analyze NIFFLs' participation in a forestry assistance program in Indiana (USA). Their results showed that age, fear of loss of property rights, membership in forestry organizations, and total land owned influenced their willingness-to-participate in some forest public programs. Using principal component analysis, it was found that active members, sufficiency of work, use of published material, and the availability of capital and credit are important variables that explained variations in participation [29]. Forest policy and institutions promoting landowner cooperation also seem to influence NIFFLs' reforestation and harvesting decisions [43]. Government support, including access to capital and technological assistance, can strengthen NIFFLs cooperation and in turn encourage forest management. Government action favoring adjustments in ownership rights such as land tenure reform or support for collective action through cooperatives can also significantly influence NIFFLs behavior.

Cooperative-managed forests seem to be sustainably managed [15]. Forest cooperatives have been in part developed to manage forests at a larger scale beyond individual households in an effort to attain multiple targets ranging from timber production, ecotourism, and environmental protection [29]. Cooperatives provide an organized institutional framework and offer many advantages to members. Private family landowners, as members of cooperatives, get opportunities to learn and share information with others and gain access to the creation of economies of scale, as well as enhance the stability and cohesiveness in the local community [44]. NIFFLs often join forest cooperatives or similar organizations to collectively manage forests in over nineteen countries [15, 27, 28, 45]. In Western and Nordic European countries, private landowner cooperatives have been successfully established. Local forest cooperatives are involved in educating landowners about forestry practices to improve privately owned forestlands' health and productivity. At the same time, forest cooperatives benefit the local economy by maximizing the economic returns to the landowners from their forest resources. Countries with developed economies and high-population density like Japan, the Netherlands, Germany, France, and Belgium promote cooperation among small private owners to secure greater public funding and government financial support [15, 46]. Previous research suggests broad landowner interest in cooperation for forest management at scales larger than individual parcels [46]. Following the experience of other countries, and in order to achieve economies of scale and address problems such as small-scale of production by NIFFLs, limited capacity of market competition, and shortage of laborers, the Chinese central government has encouraged NIFFLs to adopt various forms of cooperatives.

2.3. Development of Forest Cooperatives in China. The historic development process of a forest cooperative generally involved three phases. The first is a self-determined cooperation phase, dating back to 1952, where forest landowners form groups to assist with afforestation and forest harvesting. A second phase was developed during the people's commune (the commune period in China took place during 1958 to 1978. The framework for rural development throughout China at the time was provided by the people's commune. In the communes, the ownership of land, farming-implements, and animals was vested at the community level. Commune members could only earn income from farming at the time [47]) period. In this phase, forest farmers lost the property right over their lands to people's commune which resulted in the absence of private forest landowners' cooperation. The third phase corresponds to formal reorganization. Since the Third Plenary Session of the Eleventh Communist Party of China Central Committee, with the implementation of rural household responsibility system with remuneration linked to output, the collective forest management system has been reformed. However, the limitations of this family-centered management model were increasingly highlighted with the development of the socialist market economy [7].

At present, three main types of forest cooperative models have been formed in China. The first type is household cooperative forest farms or rural cooperative forest farms formed by several households. During the process of forest tenure reform, some forestlands included many households and the area distributed per household was too small to render economically feasible to manage, so households had a motivation to aggregate their forestlands. The forestlands could then be appraised and converted into shares. This kind of cooperative's main income comes from timber harvest. Cooperative members derive income based on the original 
property investment and forestland value. The second type of institutional model corresponds to a nonprofit organization by a local village committee with the main objective of protecting the local environment. Commonly, a local government provided fixed funds and members received compensation from forest ranging, firefighting, pest, or disease $[16,48-$ $50]$. The third type of forest cooperative main provides production and processing sales service to their members for certain products. This kind of cooperative is usually developed by landowners with higher-than-average knowledge of land management and product commercialization. One example is a "bamboo shoots" cooperative where bamboo shoots are purchased from members at prices that are slightly higher than market prices paid to noncooperatives and members are employed to do the primary processing (e.g., shelling and packing). This practice enhances product added value and improves members' income. The bamboo shoots are then sold by the cooperative. This latter type of cooperative is the most popular in China. The operation of specialized forest products cooperatives mainly includes nonwood products such as organic vegetables, fruit and medicinal plants, processing and marketing, transportation, and monitoring and prevention of illegal logging and poaching. In some southern villages, bamboo lumber harvesting, processing and sale are the main tasks of local forest cooperatives [50]. There are an estimated 64,000 forest cooperatives involving 18.46 million households and covering about two million hectares of forestland in China [12].

\section{Methods}

3.1. Study Area and Data Collection. The study area included two provinces in Southern China: Fujian and Jiangxi (Figure 1). These two provinces were chosen for two major reasons. First, the forest industry is pivotal to the local rural economy in these provinces thanks to the rich endowment of forest resources and forestland coverage in both provinces exceeds $60 \%$. Second, these provinces were pilot areas during the first phase of land tenure reform which has resulted in relatively better-defined property rights compared to other parts of the country. These two factors have allowed for the emergence of forest cooperatives in the two provinces that allows for a better assessment of landowner perceptions. As of 2010, forestland in Fujian province accounted for $73.2 \%$ of this total land area, $42.9 \%$ of the population lived in rural areas, and more than 20 thousand forest cooperatives have been established [51]. Similarly, in Jiangxi province, $64.21 \%$ of the total land is forestland, more than half of the population lived in rural areas, and there were over 14 thousand forest cooperatives of various types by 2010. Table 1 provides summary of statistics about forest resources and socioeconomic information in Fujian and Jiangxi Provinces.

Face-to-face surveys were conducted from May 2010 to February 2011. A total of 310 randomly selected households (representing about $1.38 \%$ of the total population) in twelve villages from four counties (Youxi and Shaowu county in Fujian province, Suichuan and Tonggu county in Jiangxi province) participated in this study. These four counties were selected by the central Government to enter the collective forest tenure reform which provided a motivation for this target sample of individuals exposed to the tenure reform process and subsequent creation of cooperatives. A faceto-face method was selected due to the fact that highpoverty and low-education levels coupled with low economic development limited the use of other data collection tools (e.g., mail or web-based surveys). For each county included in the survey, a list was collected from the local Forestry Bureau that compiles the most recent data on land ownership. Considering the distances to each county and accessibility conditions, twelve villages were randomly selected from these four counties. Six of these villages were selected for each province: two villages Mayang and Shanlian in Youxi county, four villages Jiashang, Xiedun, Shangdu, and Jiagao in Shaowu county, four villages Fumin, Shangfu Shikeng, and Guixi in Suichuan county, two villages Gaopi and Dacao in Tonggu county. In each village, 30 households were selected at random from household registration records. Local forestry officials pointed to the location of each selected household but were never present during face-to-face interviews to avoid potential bias [52]. The original target was to collect 360 samples, but once completed only 310 questionnaires in total were available for analysis. The reasons for the missing 50 observations were that landowners were not at home when visited, some landowners refused to participate in the survey, and others lived in a road-less area that impeded access.

Standardized interview methods were used for this study. Before starting the interview, the purpose of the survey was outlined to participants followed by an explanation of a forest cooperative. A forest cooperative was described as a form of organization created to assist in meeting the members' various forest management needs and to help them gain more benefits from their forestland. The survey instrument contained a variety of questions related to demographic information (e.g., households' age, education, and income), area, forest management activities (e.g., the reasons for household owning forestland and whether they have transferred forestland to other household or forestry enterprise). Landowners' attitudes toward forest tenure reform and cooperatives were also gathered. Examples of these included "Do you know about forest cooperatives?; Would participating in forest cooperatives be helpful to you?; Has the forest tenure reform been good to you?" All questions were presented in Chinese. Average completion time for each questionnaire was about two hours per household.

3.2. Empirical Model. Since the dependent variable in the study was binary (willingness-to-participate in a cooperative or not), a logistic regression was used to estimate model coefficients. This binary functional form was preferred to ease result interpretation. The model was designed to explore the association between NIFFLs' willingness-to-participate in forest cooperatives and forest management, socioeconomic and demographic characteristics. The association between a dichotomous dependent variable and multiple independent 


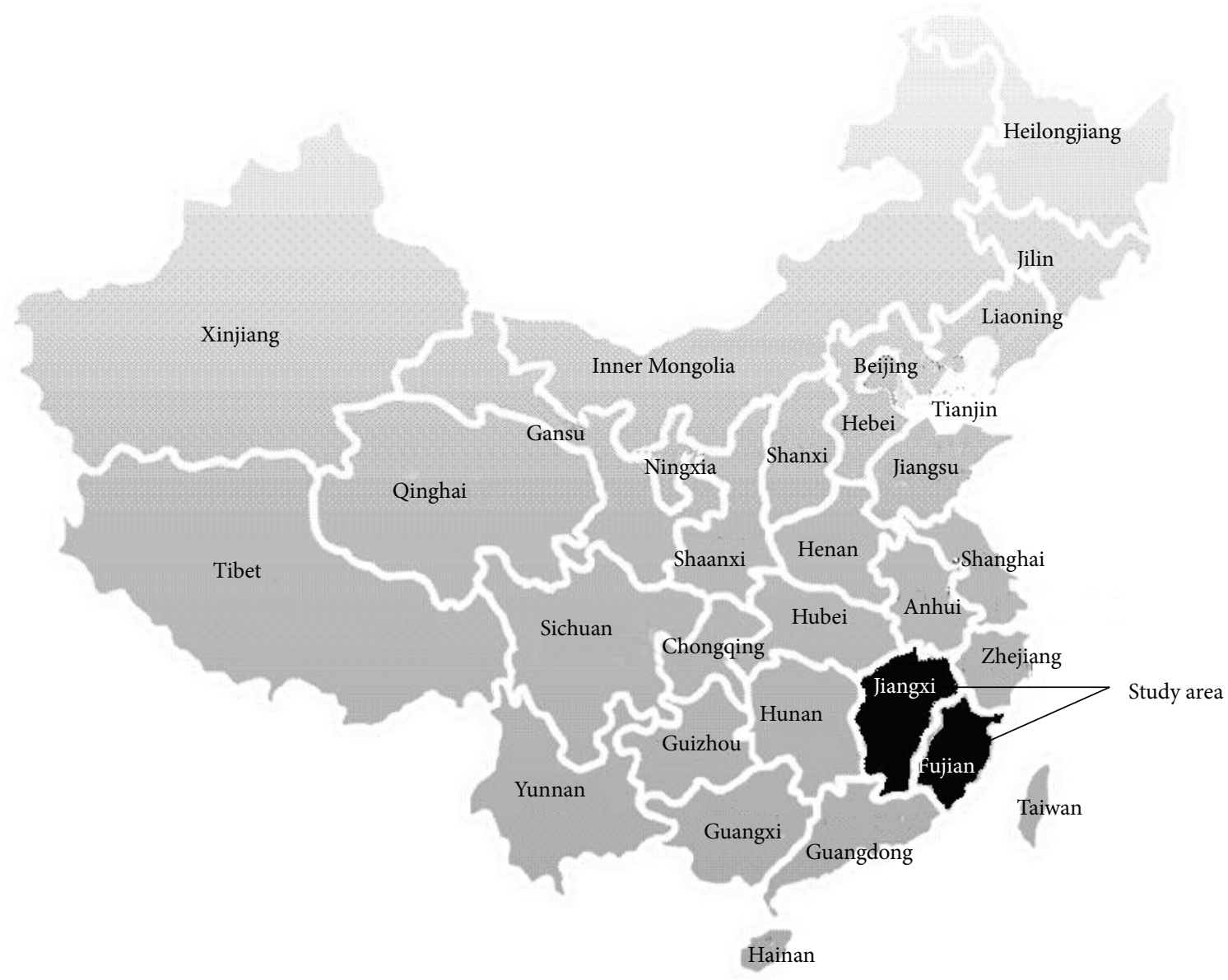

FIGURE 1: Map of study of area location, Fujian and Jiangxi provinces.

variables was analyzed following Greene and Zhang [32] and Jarrett et al. [53]:

$$
\operatorname{Logit}(P)=\operatorname{Ln}\left(\frac{p}{1-p}\right)=\alpha+X^{\prime} \beta,
$$

where $P$ is the probability of a NIFFL that stated to be willing to participate in a forest cooperative. $X$ is a vector of independent variables, and $\alpha$ and $\beta$ are regression coefficients. $P$ can be derived as

$$
P=\operatorname{prob}(Y=1 \mid X)=\frac{e^{x^{\prime} \beta}}{1+e^{x^{\prime} \beta}}=E(Y \mid X) .
$$

The likelihood function represents an individual's stated willingness-to-participate in a forest cooperative of each observation (3). Prior to econometric estimation, the model was tested for heteroskedasticity using a Breusch-Pagan test $[32,54]$,

$$
l=\prod_{i=1}^{n} p_{i}^{y_{i}}\left(1-p_{i}\right)^{1-y_{i}} .
$$

The empirical model explored the relationship between the dependent variable (WILLINGNESS) that captures landowners' stated willingness-to-participate in a forest cooperative and independent variables as follows:

\section{WILLINGNESS}

$$
\begin{aligned}
= & \beta_{1} \text { AGE }<60+\beta_{2} \text { EDUCATION } \\
& +\beta_{3} \text { HEALTH }+\beta_{4} \text { LEADER } \\
& +\beta_{5} \text { WORKINGDIVID }+\beta_{6} \text { FORESTACT } \\
& +\beta_{7} \text { OUTSIDEWORK }+\beta_{8} \text { INCOME } \\
& +\beta_{9} \text { L_AREA }+\beta_{10} \text { TRANSFER } \\
& +\beta_{11} \text { HEARDFC }+\beta_{12} \text { FUNTIONFC } \\
& +\beta_{13} \text { F_REFORM }+e,
\end{aligned}
$$

where WILLINGNESS took the value of " 1 " if the NIFFL indicated willingness to be a member of a forest cooperative and " 0 " otherwise. Independent variables included the respondent's age (if under 60), education, and health, whether the respondent was one of the village committee leaders, the number of working household individuals, whether the household had been engaged in forestry activities, employment and percent of total household income from forestryrelated activities, logarithm of the household's forestland 
area, whether the household's forestland had been previously transferred, whether the respondent has heard of forest cooperatives, if participating in forest cooperatives was deemed helpful to the respondent, and whether the forest tenure reform was perceived to be beneficial to the respondent. Table 2 lists the descriptions of the dependent variable and explanatory variables that were included in the logistic model (Table 2).

The selection of explanatory variables was based on past studies indicating that the main factors affecting NIFFLs' participation in a cooperative include local policy, access to nonfarm jobs, forest management experience, local economic development, and households' profile characteristics [30]. Based on field experience, casual evidence, and other studies, a set of hypotheses were proposed regarding the effect of explanatory variables (Table 2). For example, it was hypothesized that younger NIFFLs and those possessing a higher levels of education were more likely to be members in a cooperative since they are more likely to be receptive to innovative ideas [42, 55-58].

In our questionnaire design, we judged whether the respondent was in "good health" by determining whether the respondent was capable of carrying out forest management activities such as reforestation. If a respondent was physically disabled in a manner that impaired her/his working ability or had lost or partially lost working capacity due to a disease or illness s/he was categorized to be in poor health. In the absence of these conditions good health was reported. It was hypothesized that a forest owner in poor health condition would be more likely to join forest cooperatives because of potential assistance benefits from the cooperative. The education of the respondent was expected to be positive while the willingness-to-participate in forest cooperative, age $<60$, and health condition of the respondent were expected to be inversely correlated. Similarly, we anticipated the variable LEADER to be positive because the village committee leader is often more familiar with the land tenure reform policy and might tend to be early adopters. Some studies indicate that the number of working household individuals has a negative influence on willingness-to-participate in a forest cooperative $[57,59]$. A household with fewer able-to-work individuals would be more likely to participate in a cooperative under the premise that the household could receive additional assistance [60]. Hence, the variable WORKINDIVID was expected to have a negative correlation with WILLINGNESS. The variable OUTSIDEWORK was expected to be negative because family members who work outside the land do not tend to focus on forest management as a major source of income [56].

The coefficients for WORKINDIVID and FOREST ACTV were expected to be positive. If forestry was reported to be very important to households, they would likely pay more attention to adopting and improving forest management [42]. In the questionnaire, "the family has long been engaged in forestry activities behavior" was judged by the average number of working hours spent per year on forestryrelated duties. If the family spent more than six months in a year on forest management, the family was classified to being engaged in forestry activities. Being engaged in forestry activities was expected to have a positive correlation with WILLINGNESS. Likewise, landowners with relatively larger areas of forestland were deemed to need more capital investment and potentially face more production and operations management problems than those with smaller areas of forestland. Thus, their willingness to seek help from forest cooperatives would be stronger [31]. We assumed a negative relationship between transferred forestland and WILLINGNESS. Respondents who have transferred forestland could receive rent from other household or the forestry enterprise and therefore may not likely need to manage forestry in their lease term.

Three questions related to institutional variables were used to elicit respondents' attitudes toward certain policies [42]. If a respondent had heard of forest cooperatives and considered that this kind of organization could help ameliorate forest management problems, s/he may be more likely to participate in a forest cooperative. The forest tenure reform has now been in progress for various years, and its effects are better known by forest landowners. The probability of willingness-to-participate in forest cooperatives was hypothesized to increase with a positive perception that collective forest tenure reform would be beneficial to a household.

\section{Results}

4.1. Descriptive Statistics. Descriptive statistics are presented in Table 3. The average age of the respondents was 50.92 years; among the five age groups $(<30,31-40,41-50,51-60,>60)$, the largest percentage of respondents was between $41-50$ years respondents under 30 years of age corresponded to the smallest group. Respondents' education levels were generally low, with $33.87 \%$ of participants with a primary school education and $42.9 \%$ holding middle school education. Illiteracy level in the sample was $7.10 \%$. According to the China National Bureau of Statistics, in 2010 the average farmer's per capita income was $¥ 5,789$ in Jiangxi province and $¥ 7,427$ in Fujian province. We used the two provinces average income of $¥ 6,608$ as the standard to judge the living condition of the participant, whether at, above, or below average income. Only $51.61 \%$ of the participants in our sample reported to earn an annual income above average.

An average family in the study had 2.7 working household individuals and $10.97 \%$ of all respondents were reported to be in "poor health". About $14.19 \%$ of respondents identified themselves as being leaders of their village committee. Nearly $58.06 \%$ of surveyed households had part-time work elsewhere. Of the three categories of total income levels (less than $¥ 7,000 ; ¥ 7,000-20,000$; and more than $¥ 20,000$ ), $62.22 \%$ of respondents had an annual income of less than $¥ 7,000$ per year. The sample had $17 \%$ of respondents with an annual income in the range of $¥ 7,000-20,000$ per year and $19.68 \%$ with an annual income greater than $¥ 20,000$. Average per family area of forestland was 3.81 ha. Thirty-nine percent of respondents considered it helpful to participate in a forest cooperative, $14.84 \%$ thought that it provided no benefit $(53.87 \%$ of respondents did not know what a forest cooperative was or its function). Regarding attitudes toward 
forest tenure reform, $56.77 \%$ respondents agreed to the statement regarding it being beneficial, $36.45 \%$ were neither in agreement or disagreement, $5.48 \%$ were in disagreement, and $1.23 \%$ gave no answer. The percent of respondents willing to participate in forest cooperatives was $54.52 \%$ (Table 4 ).

4.2. Logistic Regression Analysis. The Breusch-Pagan test failed to reject the null hypothesis for the presence of heteroskedasticity. Estimates for willingness-to-participate in forest cooperatives are presented in Table 5. The model was found to be significant at the $95 \%$ confidence level. Because of missing data only 286 observations were used in the final regression model.

The estimated coefficient for variable AGE was not statistically significant $(P<0.05)$, although it had a positive sign. This can be explained by the lack of variability in responses but a majority of positive views. Fifty-nine percent of the respondents who were less than 60 years old and $42 \%$ of respondents who were older than 60 years indicated that they would like to participate in a forest cooperative. The estimated coefficient for variable EDUCATION was positive and statistically significant at $P<0.01$. Results indicate that the odds of willingness-to-participate in a cooperative would increase by $76 \%$ for each level increase in the respondent's education. The coefficient for HEALTH suggests an inverse relation between reported health condition and willingnessto-participate in a forest cooperative. A respondent identified as being in good health condition was $84 \%$ less likely to respond affirmatively to the question regarding cooperative participation. The estimated coefficients for variable LEADER were positive and significant at $10 \%$ type-I error. The number of working household individuals had little influence on NIFFLs' stated willingness-to-participate in forest cooperatives. If the proportion of forestry income by forestland was greater the willingness-to-participate in a cooperative was also higher. Similarly, the estimated coefficient for whether the household was engaged in forestry activities (FOREST_ACTV) was found to be positive and significant at $\alpha=0.01$. As expected, the estimated coefficient for variable OUTSIDEWORK was negative and statistically significant. Seventy-two percent of respondents whose family members worked outside would not be likely to participate in forest cooperatives. The estimated coefficients for variables INCOME and L_AREA were positive and significant at the $\alpha$ $=0.05$ level. The estimated coefficient for variable TRANSFER was negative and significant at $\alpha=0.05$. Respondents' attitudes towards forest cooperatives and forest tenure reform had the expected and effects on WILLINGNESS.

\section{Discussion}

This research identified some of the variables in our regression model to be correlated with NIFFLs' willingness-toparticipate in a forest cooperative in Southern China. As expected, the variable AGE was found to be positively associated with WILLINGNESS, but the result was not statistically significant (arguably linked to the lack of age variability in the sample). Results were consistent with the hypothesis that people with higher education would be more likely to participate in cooperatives. This argument is supported by the literature that shows that higher levels of education help people better understand a forest cooperative's prospects and can maximize its benefits. Landowners with a higher level of education may be more willing to accept new ideas such as new organizational structures. The variable HEALTH was negatively significant at $P<0.01$. If landowners were in a poor state of health, they might be more likely to manage their forestland cooperatively instead of by themselves; participation in a cooperative can alleviate problems associated with labor shortages. Whether the respondent was a village leader or village committee member, the villager's position was related to their decision in forest management. In rural areas, the village leader might have stronger capability to collect information and accept new ideas than other forest farmers. Moreover, these landowners could have more opportunities to get resources, receive information, and understand what a forest cooperative is, thus becoming more willing to participate in forest cooperatives for expanding production scale and integrating resources.

The variable WORKINDIVID was negatively correlated but had no statistically significant effect on WILLINGNESS. In the study area people having part time jobs outside the household property were common. If family members have jobs outside the village, they might not be too dependent on agriculture and forest management. Landowners can earn more money from nonforestry jobs, so they might not find joining a forest cooperative as an alternative to raise income. However, a family that is engaged in forestry production and receives a large percent of their income from forestry would be more likely to participate in forest cooperatives, partly for scale management purposes. Similarly, if a household is more dependent on forest management as a source of income, such a household will be more likely to join a forest cooperative as a tool to have better access to knowledge and practices to enhance forest management. When face-to-face interviews were conducted, we recognized that most of NIFFLs lived in remote mountainous areas, where accessibility to markets is poor and information is limited. Therefore, the NIFFLs rely primarily on the local government and nongovernment organizations to obtain more market information and training.

Yang [16] considers a forest cooperative to be a new type of rural economic cooperative organization in China primarily created to enhance forest product and forest byproduct processing and marketing. Larger areas of forestland can increase forest management by reducing costs per acre, which could in turn raise enthusiasm in cooperative participation among NIFFLs. This was supported by our finding with the positive and significant sign of the coefficient L_AREA. To the contrary, transferring lands to other tenants would reduce expected adoption of forest management practices and potential revenues. In turn, lower expected benefits would reduce the motivation to participate in a forest cooperative which might be captured by the negative and statistically significant coefficient for TRANSFER.

Findings suggest that respondents who understand and are familiar with China's forest tenure reform are more likely to participate in a cooperative. NIFFLs that have heard and 
TABLE 1: Forest resources and socioeconomic information in Fujian and Jiangxi provinces.

\begin{tabular}{|c|c|c|}
\hline Main index & Fujian province & Jiangxi province \\
\hline Total land area (ha) & $12,400,000$ & $16,695,000$ \\
\hline Forestland area (ha) & $9,070,000$ & $10,720,000$ \\
\hline Forest coverage & $63.1 \%$ & $60.05 \%$ \\
\hline Population (thousand) & 36,930 & 44,623 \\
\hline $\begin{array}{l}\text { Output value of forest sector } \\
\text { (million) }\end{array}$ & 16,220 & 16179 \\
\hline $\begin{array}{l}\text { Average rural income } \\
\text { (Yuan) }\end{array}$ & 7,427 & 5,789 \\
\hline $\begin{array}{l}\text { Quantity of rural population } \\
\text { (thousand) }\end{array}$ & 15,850 & 25,184 \\
\hline Quantity of forest cooperatives & 24,887 & 14,012 \\
\hline
\end{tabular}

Source: Jiangxi Statistical Yearbook (2010) [61]; Fujian Statistical Yearbook (2010) [62].

understand the purpose of forest cooperatives exhibited a higher probability of participating in forest cooperatives, about $98 \%$ higher than those with no knowledge. Fiftythree percent of respondents have heard of forest cooperatives, but among them $32 \%$ households did not know forest cooperatives' function and $20 \%$ households considered forest cooperatives useless for forest management. The latter may suggest a need for increasing awareness about cooperatives and their benefits. To a large extent, if forest cooperatives in China were better developed and with a proven record of successful forest management, they might encourage greater landowner participation. Results showed that the respondents' attitude toward forest tenure reform had a strong association with their willingness-to-participate in forest cooperatives. The development of forest cooperatives was preceded by the transferring of ownership rights. One being a precursor to the other; it was expected that a positive view of the forest land tenure reform would be positively associated with WILLINGNESS.

\section{Conclusions}

Forest cooperatives can potentially provide several benefits to NIFFLs including improvements in shared information, equipment, and experience, better access to financial assistance, and educational and training opportunities. These conditions can facilitate the adoption of forest management plans and as a result improve the local environment and forest-based production among other market and nonmarket benefits. In this study, a sample of NIFFLs in Fujian and Jiangxi provinces in China was sampled via face-to-face interviews with the aim of determining factors associated with NIFFLs' willingness-to-participate in forest cooperatives.

Findings show that various explanatory variables significantly influenced NIFFLs' stated willingness-to-participate in forest cooperatives. Landowners' profile characteristics including education level, physical health, and holding a leader's position in a village showed statistical significance association with WILLINGNESS. Among household descriptors, household-related forest management activity and subsequent income had a positive association with willingnessto-participate in a forest cooperative, while having a nonrelated forest job had a negative association. The area of forestland owned and whether forestland has been transferred to other tenants were resource-related variables that showed a strong statistical significance. NIFFLs' attitude towards the benefits derived from the forest land tenure reform and cooperative participation was also strong descriptors for WILLINGNESS.

In order to further develop forest cooperatives in China, findings of this study point to several suggestions. First, given that a large number of NIFFLs (45\%) expressed skepticism to participate in forest cooperatives, a full range of communication tools to improve education and outreach might be needed. Results of the logistic regression showed the positive and significant effect of favorable attitudes towards reform and benefits from joining a cooperative on NIFFLs' willingness-to-participate. Information about the land tenure reform process and how it can facilitate the creation of forest cooperatives should be conveyed to landowners quickly and comprehensively. Local governments should provide more opportunities to help landowners enhance their educational level.

Second, central government policy makers and local government officials, in addition to enhancing public awareness, should perhaps offer financial assistance to encourage greater participation (e.g., ease access to loans at competitive rates). Findings show a strong association between forest-related income, active management, and expected benefits, with willingness-to-participate in a cooperative. Any incentives that can increase net income to households will be conducive to greater NIFFL participation. Among the various organizational forms of cooperatives the type that enhances production and value-added to forest products may be the best positioned to be the most-widely adopted, increasing monetary benefits to landowners while also promoting forest management. Given that most forest cooperatives in China are still in an early stage of development, the operational model of the cooperative needs to be improved so as to make full use of the members' enthusiasm and creativity. Cooperatives should adopt flexible and diversified management models.

Third, leadership and professional management of forest cooperatives are instrumental to their success. With regard to the formation of a cooperative, this is chiefly driven by leading members of a village, often community early adopters, and then followed by the other NIFFLs. The variable in our model capturing leadership role in a village supported the argument that leaders' role in promoting the development of forest cooperatives must be central to public efforts encouraging cooperative formation. Cooperatives can help disseminate better forest management so that the objective of the land tenure reform of increasing short-term earnings is not coupled with long-term detrimental effects to the forest resource. China's forestry may be classified as being at an early stage of development and forestry operations commonly face poor technical and managerial skills. It is important to 
TABLE 2: Description of dependent variable and explanatory variables used in the logistic regression model.

\begin{tabular}{|c|c|c|}
\hline Variable code & Description & Expected effect \\
\hline \multicolumn{3}{|l|}{ Dependent variable } \\
\hline WILLINGNESS & Stated decision to join in forest cooperatives, 1 if willing, 0 otherwise & NA \\
\hline \multicolumn{3}{|l|}{ Explanatory variables } \\
\hline \multicolumn{3}{|c|}{ Landowner profile variable } \\
\hline AGE $<60$ & 1 if respondent is younger than 60 years, 0 otherwise & + \\
\hline EDUCATION & $\begin{array}{l}1=\text { illiterate, } 2=\text { primary school, } 3=\text { middle school, } 4=\text { high school, } \\
5=\text { college } \text { or above }\end{array}$ & + \\
\hline HEALTH & Whether respondent is in good health $(1=$ healthy, $0=$ unhealthy $)$ & - \\
\hline LEADER & Whether respondent is a village committee leader $(1=$ yes, $0=$ no $)$ & + \\
\hline \multicolumn{3}{|l|}{ Household variable } \\
\hline WORKINDIVID & Number of working individuals in a household & - \\
\hline FOREST_ACTV & Whether the household has been engaged in forestry activities $(1=$ yes, $0=$ no $)$ & + \\
\hline OUTSIDEWORK & Whether the family member working outside $(1=$ yes, $0=$ no $)$ & - \\
\hline INCOME & Percentage of forestry income in total household annual income (\%) & + \\
\hline \multicolumn{3}{|c|}{ Resource endowment variables } \\
\hline L_ACREAGE & Logarithm of the forest acreage of the household $\left(\mathrm{mu}^{*}\right)$ & + \\
\hline TRANSFER & Whether household has transferred forestland to others $(1=$ yes, $0=$ no $)$ & - \\
\hline \multicolumn{3}{|l|}{ Institutional variables } \\
\hline HEARDFC & Whether respondent has heard of forest cooperatives $(1=$ yes, $0=$ no $)$ & + \\
\hline FUNCTIONFC & $\begin{array}{l}\text { Participating in forest cooperatives is helpful to you } \\
(1=\text { strongly agree, } 2=\text { agree, } 3=\text { disagree, } 4=\text { don't know })\end{array}$ & - \\
\hline F_REFORM & $\begin{array}{l}\text { Forest tenure reform participation would be beneficial to you } \\
(1=\text { agree, } 2=\text { neither agree nor disagree, } 3=\text { disagree })\end{array}$ & - \\
\hline
\end{tabular}

${ }^{*} 1 \mathrm{mu}=0.067$ ha. NA: not applicable.

TABLE 3: Demographic characteristics of nonindustrial family forest landowners sampled in Fujian and Jiangxi provinces.

\begin{tabular}{lcc}
\hline Features & Frequency & Percent \\
\hline Age (years) & & \\
$\quad<30$ & 6 & 1.94 \\
$31-40$ & 61 & 19.68 \\
$41-50$ & 99 & 31.94 \\
$51-60$ & 78 & 25.16 \\
$>60$ & 66 & 21.29 \\
Minimum education & & \\
Illiterate & 22 & 7.10 \\
Primary school & 105 & 33.87 \\
Middle school & 133 & 42.90 \\
$\quad$ High school & 43 & 13.87 \\
College or above & 7 & 2.26 \\
Local annual income (in Yuan, $\left.¥^{*}\right)$ & & \\
Less than average $(\leq ¥ 6,608)$ & 150 & 48.39 \\
Greater than average $(>¥ 6,608)$ & 160 & 51.61 \\
\hline
\end{tabular}

${ }^{*}$ U.S.\$ $1=$ Yuan 6.63 at the time of the survey.

increase the training of the technical and managerial capacity of the forest cooperatives and the role of government and nonprofit organizations will be instrumental.
TABle 4: Non-industrial family forest landowners' stated willingness-to-participate in forest cooperatives.

\begin{tabular}{lccc}
\hline $\begin{array}{l}\text { Willingness-to-participate } \\
\text { in forest cooperatives }\end{array}$ & Value in model & Frequency & Percent \% \\
\hline Yes & 1 & 169 & 54.52 \\
No & 0 & 141 & 45.48 \\
\hline Total & - & 310 & 100 \\
\hline
\end{tabular}

Arguably, a public effort that targets larger areas of forest ownership (i.e., larger parcel sizes) should be a strategic priority to widen the area of forests managed under cooperatives in the immediate term. Larger parcels, that can facilitate management due to the benefits of economies of scale, lower transaction costs, marketing, among others, might be the focus of national and provincial outreach strategies. Like in many other parts of the world, the greatest challenge to wider cooperative adoption may remain with the NIFFLs with smallest ownerships for whom forestrelated represents a small share of their income. Finally, forest sector policy makers should expand funding to support forest cooperatives and local governments establishing formal laws that govern forest cooperatives in detail to avoid confusion and clearly state stakeholders' roles and objectives. However, although providing a legal framework, any law of cooperatives should 
TABLE 5: Results of logistic regression on willingness-to-participate in forest cooperatives as a function of selected explanatory variables.

\begin{tabular}{|c|c|c|c|c|c|}
\hline Explanatory variables & Coef. & Odds ratio & Std. err. & $z$ & $P>|z|$ \\
\hline AGE & 0.605 & 1.832 & 0.719 & 1.540 & 0.123 \\
\hline EDUCATION & 0.565 & 1.760 & 0.380 & 2.619 & 0.009 \\
\hline HEALTH & -1.831 & 0.160 & 0.094 & -3.130 & 0.002 \\
\hline LEADER & 0.969 & 2.609 & 1.470 & 1.702 & 0.089 \\
\hline WORKINDIVID & -0.027 & 0.974 & 0.130 & -0.200 & 0.842 \\
\hline FOREST_ACTV & 1.092 & 2.980 & 1.015 & 3.206 & 0.001 \\
\hline OUTSIDEWORK & -1.312 & 0.269 & 0.092 & -3.823 & $<.001$ \\
\hline INCOME & 0.011 & 1.011 & 0.006 & 1.974 & 0.048 \\
\hline L_ACREAGE & 0.304 & 1.355 & 0.195 & 2.111 & 0.035 \\
\hline TRANSFER & -1.089 & 0.336 & 0.146 & -2.512 & 0.012 \\
\hline HEARDFC & 0.978 & 2.658 & 0.928 & 2.800 & 0.005 \\
\hline FUNTIONFC & -0.460 & 0.631 & 0.108 & -2.688 & 0.007 \\
\hline F_REFORM & -0.912 & 0.402 & 0.120 & -3.052 & 0.002 \\
\hline CONSTANT & 1.277 & 3.586 & 1.207 & 1.060 & 0.290 \\
\hline
\end{tabular}

Number of observations $=286$; $\log$-likelihood ratio $\mathrm{Chi}^{2}(13)=145.55$; pseudo $R^{2}=0.369$. Log-likelihood $=-124.283 ;{\text { Prob }>\mathrm{Chi}^{2} \leq 0.001}$

be flexible to accommodate local socioeconomic, cultural and natural, resource conditions.

\section{Acknowledgments}

Financial support was provided by the United Nation's Food and Agriculture Organization (FAO) to Beijing Forestry University of China under the Program "Supporting Policy, Legal and Institutional Frameworks for the Reform of Forest Tenure in China's Collective Forests and Promoting Knowledge Exchange" (GCP/CPR/038/EC). The authors thank Lana Narine, Marissa "Jo" Daniel, and Dr. Zhen Cai for helpful comments to earlier versions of this paper.

\section{References}

[1] R. Yin, "Forestry and the environment in China: the current situation and strategic choices," World Development, vol. 26, no. 12, pp. 2153-2167, 1998.

[2] P. Zhang, G. Shao, G. Zhao et al., "China's forest policy for the 21st century," Science, vol. 288, no. 5474, pp. 2135-2136, 2000.

[3] Y. Shen, Y. Zhnag, X. Xu, Z. Zhu, and C. Jiang, "Towards decentralization and privatization of China's collective forestlands: a study of nine villages in 3 provinces," International Forestry Review, vol. 11, no. 4, pp. 456-463, 2009.

[4] Y. Zhang, J. Uusivuori, and J. Kuuluvainen, "Impacts of economic reforms on rural forestry in China," Forest Policy and Economics, vol. 1, no. 1, pp. 27-40, 2000.

[5] J. Xu, A. White, and U. Lele, China's Forest Tenure Reforms: Impacts and Implications for Choice, Conservation, and Climate Change: Rights and Resources Initiative, Peking University Press, Beijing, China, 2010.

[6] S. Rozelle, J. Huang, and V. Benziger, "Forest exploitation and protection in reform China: assessing the impact of policy, tenure and economic growth," Working Paper, Agricultural Economics, University of California Davis, 2003.

[7] S. Wang, G. C. Van Kooten, and B. Wilson, "Mosaic of reform: forest policy in post-1978 China," Forest Policy and Economics, vol. 6, no. 1, pp. 71-83, 2004.
[8] J. Y. Lin, "Rural reforms and agricultural growth in China," American Economic Review, vol. 82, no. 1, pp. 34-51, 1992.

[9] W. F. Hyde, B. Belcher, and J. T. Xu, China's Forests: Global Lessons from Market Reforms, Resource for the Future, Washington, DC, USA, 2003.

[10] The Central People's Government of the People's Republic of China (CPGPRC), "Decision of accelerating development of forestry," 2003, http://www.gov.cn/gongbao/content/2003/ content_62358.htm.

[11] State Forestry admimistrition, P.R. China (SFA), "The lecture of Jia Zhibang in national forestry bureau director conference," 2011, http://www.forestry.gov.cn/portal/main/s/90/content460300.html.

[12] X. Su, "The enlightenment from Japanese forestry combination for China's development of forestry cooperative organization," Forestry Economics, vol. 2, pp. 92-96, 2011 (Chinese).

[13] International Co-operative Alliance (ICA), "Statement on the Co-operative Identity," 2007, http://www.ica.coop/coop/ principles.html.

[14] United States Department of Agriculture, "Agricultural cooperatives in the 21st century," 2002, http://www.rurdev .usda.gov/rbs/pub/cir-60.pdf.

[15] D. B. Kittredge, "The cooperation of private forest owners on scales larger than one individual property: international examples and potential application in the United States," Forest Policy and Economics, vol. 7, no. 4, pp. 671-688, 2005.

[16] Y. Yang, "Opinions on cultivation and development of forestry economic cooperation organizations in rural areas," Liaoning Forestry Science and Technology, vol. 5, pp. 40-42, 2006 (Chinese).

[17] M. G. Jacobson, R. C. Abt, and D. R. Carter, "Attitudes toward joint forest planning among private landowners," Journal of Sustainable Forestry, vol. 11, no. 3, pp. 95-112, 2000.

[18] M. J. Jones, Evaluation of honduran forestry cooperatives: five case studies [M.S. thesis], Michigan Technological University, Houghton, Mich, United States, 2003.

[19] M. G. Rickenbach, R. P. Guries, and D. L. Schmoldt, "Membership matters: comparing members and non-members of NIPF owner organizations in southwest Wisconsin, USA," Forest Policy and Economics, vol. 8, no. 1, pp. 93-103, 2006. 
[20] M. G. Rickenbach, “Cooperative functions: meeting members' needs, in Proc. of conf. on Forestry cooperatives: what today's resource professionals need to know, Jakes, P.J. (comp.) US For. Serv.Gen," Tech. Rep. NC-GTR-266, North Central Forest Experiment Station, St. Paul, Minn, USA, 2006.

[21] L. Alexander, Nonindustrial private forest landowner relations to wildlife in New England [Ph.D. thesis], Yale University, New Haven, Conn, United States, 1986.

[22] T. W. Birch, "Private forest-land owners of the United States, 1994," Resource Bulletin NE-134. US Department of Agriculture, Forest Service, Northeastern Forest Experiment Station, Radnor, Pennsylvania, 1996.

[23] A. F. Egan, "From timber to forests and people: a view of nonindustrial private forest research," Northern Journal of Applied Forestry, vol. 14, no. 4, pp. 189-193, 1997.

[24] A. O. Finley and D. B. Kittredge, "Thoreau, Muir, and Jane Doe: different types of private forest owners need different kinds of forest management," Northern Journal of Applied Forestry, vol. 23, no. 1, pp. 27-34, 2006.

[25] D. Hägglund, "European forest owner organisations-forest owner cooperation: main figures, aims and goals," CEPF, September 2008.

[26] K. Hogl, M. Pregernig, and G. Weiss, "What is new about new forest owners? A typology of private forest ownership in Austria," Small-Scale Forestry, vol. 4, no. 3, pp. 325-342, 2005.

[27] D. B. Kittredge, "Private forestland owners in Sweden: largescale cooperation in action," Journal of Forestry, vol. 101, no. 2, pp. 41-46, 2003.

[28] D. B. Kittredge, "Forest owner cooperation around the world: where, how, and why it succeeds," in Forestry Cooperatives: What Today's Resource Professionals Need to Know. Proceedings of a Satellite Conference, P. Jakes, Ed., US for Serv. Gen. Tech. Rep. NC-GTR-266, pp. 31-38, North Central Forest Experiment Station, St. Paul, Minn, USA, 2006.

[29] E. Atmiş, H. B. Günşen, B. B. Lise, and W. Lise, "Factors affecting forest cooperative's participation in forestry in Turkey," Forest Policy and Economics, vol. 11, no. 2, pp. 102-108, 2009.

[30] H. Huang, W. Wang, X. Wu, and Y. Huang, "Analysis of impact factor s of farmer' s participation in forest farmer associationsTaken Fujian as an Example," Forestry Economics, vol. 9, pp. 5558, 2008 (Chinese).

[31] D. Guo and W. Jiang, "The factor anylizis of landowners' behavior on partacipating in agriculture special cooperation economic organization-Case study on Zhejiang landowners," Chinese Rural Economy, vol. 5, pp. 10-16, 2004 (Chinese).

[32] W. H. Greene and C. Zhang, Econometric Analysis, vol. 5, Prentice Hall, Upper Saddle River, NJ, United States, 2003.

[33] W. B. Kurtz and B. J. Lewis, "Decision-making framework for nonindustrial private forest owners: an application in the Missouri Ozarks ( USA)," Journal of Forestry, vol. 79, no. 5, pp. 285-288, 1981.

[34] M. Rickenbach, J. Bliss, and S. Read, "Collaboratives, cooperation, and private forest ownership patterns: implications for voluntary protection of biological diversity," Small-Scale Forest Economics, Management and Policy, vol. 3, no. 1, pp. 69-83, 2004.

[35] R. A. Young and M. R. Reichenbach, "Factors influencing the timber harvest intentions of nonindustrial private forest owners ( US)," Forest Science, vol. 33, no. 2, pp. 381-393, 1987.

[36] A. Blackman, H. J. Albers, B. Ávalos-Sartorio, and L. C. Murphy, "Land cover in a managed forest ecosystem: Mexican shade coffee," American Journal of Agricultural Economics, vol. 90, no. 1, pp. 216-231, 2008.

[37] K. Willis, G. Garrod, R. Scarpa, D. Macmillan, and I. Bateman, Non-Market Benefits of Forestry: Report to the Forestry Commission Centre for Environmental Research and Appraisal, University of Newcastle, 2000.

[38] A. O. Finley, Assessing private forest landowners' attitudes towards, and ideas for, cross-boundary cooperation in western Massachusetts [M.S. thesis], University of Massachusetts, Amherst, Mass, USA, 2002.

[39] D. Belin, Assessing private landowner attitudes: a case study of New England NIPF owners [M.S. thesis], University of Massachusetts, Amherst, Mass, USA, 2002.

[40] Y. Zhang and S. Kant, "Collective forests and forestland: physical asset rights versus economic right," in Developmental Dilemmas: Land Reform and Institutional Change in China, P. Ho, Ed., pp. 249-269, Now York, NY, USA, 2005.

[41] J. L. Greene and K. A. Blatner, "Identifying woodland owner characteristics associated with timber management," Forest Science, vol. 32, no. 1, pp. 135-146, 1986.

[42] V. Nagubadi, K. T. McNamara, W. L. Hoover, and W. Mills, "Program participation behavior of nonindustrial forest landowners: a probit analysis," Journal of Agricultural and Applied Economics, vol. 28, pp. 323-336, 1996.

[43] S. A. Gregory, M. C. Conway, and J. Sullivan, "Econometric analyses of nonindustrial forest landowners: is there anything left to study?" Journal of Forest Economics, vol. 9, no. 2, pp. 137164, 2003.

[44] C. R. Blinn, P. J. Jakes, and M. Sakai, "Forest landowner cooperatives in the United States: a local focus for engaging landowners," Journal of Forestry, vol. 105, no. 5, pp. 245-251, 2007.

[45] R. B. Hull and S. Ashton, "Forest cooperatives revisited," Journal of Forestry, vol. 106, no. 2, pp. 100-105, 2008.

[46] A. O. Finley, D. B. Kittredge, T. H. Stevens, C. M. Schweik, and D. C. Dennis, "Interest in cross-boundary cooperation: identification of distinct types of private forest owners," Forest Science, vol. 52, no. 1, pp. 10-22, 2006.

[47] G. O'Leary and A. Watson, “The role of the People's Commune in rural development in China," Pacific Affairs, vol. 55, no. 4, pp. 593-612, 1982.

[48] A. He, L. Zheng, F. Mao, and X. Kong, "The effect of collective forest right system reform on the stability of rural basic management system," Journal of Nanjing Agricultural University (Social Sciences Edition), vol. 4, pp. 22-35, 2011 (Chinese).

[49] R. Lu, "Change of forest management mode after the reform of collective forest property right system in Yongding County," Subtropical Agriculture Research, vol. 3, no. 4, pp. 317-320, 2007 (Chinese).

[50] X. Kong, A. He, B. Shi, and C. Chi, "On the construction of collective forest tenure reform and forestry cooperative economic organization-based on the survey of sanming, nanping and lishui," Forestry Economics, vol. 5, pp. 17-23, 2009 (Chinese).

[51] The People's Goverment of Fujian province (PGF), “The special plan of Fujian province "the 12th five year"', farmers cooperation orgnization development, 2011, http://www.fujian.gov.cn/zwgk/ ghxx/zxgh/201108/t20110819_381083.htm.

[52] P. Qin, F. Carlsson, and J. Xu, "Forest tenure reform in China: a choice experiment on farmers' property rights preferences," Land Economics, vol. 87, no. 3, pp. 473-487, 2011. 
[53] A. Jarrett, J. Gan, C. Johnson, and I. A. Munn, "Landowner awareness and adoption of wildfire programs in the southern United States," Journal of Forestry, vol. 107, no. 3, pp. 113-118, 2009.

[54] F. X. Aguilar and Z. Cai, "Conjoint effect of environmental labeling, disclosure of forest of origin and price on consumer preferences for wood products in the US and UK," Ecological Economics, vol. 70, no. 2, pp. 308-316, 2010.

[55] I. Hammett, I. AL, F. W. Cubbage, and W. G. Luppold, "A logistical regression model of southern hardwood lumber export participation," Wood and Fiber Science, vol. 24, no. 3, pp. 315329, 1992.

[56] T. Jiang and W. Zhu, "The logit analysis on farmers particapatory in farmers specialized cooperatives-case study on Chengdu, Nanchong, Yibin, Guangqiang County, Sichuan Procince," Journal of Southwest University for Nationalities (Humans and Social Science), vol. 30, pp. 140-143, 2009 (Chinese).

[57] H. Li, F. Li, F. Chen, and J. Cao, "Analysis on the impact of Jiangxi Province farmers participating in forestry cooperation organization," Issues of Forestry Economics, vol. 30, no. 5, pp. 381-384, 2010 (Chinese).

[58] X. Lu, X. lv, and F. Qin, "Empirical analysis on farmers particapatory in farmers specialized cooperatives-based on household survey data on twenty-four counties, seven provinces," Issues in Agricultural Economy, vol. 1, pp. 16-31, 2008 (Chinese).

[59] P. C. West, J. M. Fly, D. J. Blahna, and E. M. Carpenter, "The communication and diffusion of NIPF management strategies," Northern Journal of Applied Forestry, vol. 5, no. 4, pp. 265-270, 1988.

[60] D. Zhang, L. Ding, and H. Xia, "Analysis on the farmers' desire to join in farmers' specialized cooperative organization based on the logistic model," Journal of Henan Agricultural University, vol. 3, pp. 33-341, 2007 (Chinese).

[61] China's National Bureau of Satistics, Jiangxi Statistical Yearbook 2010, China Statistics Press, Beijing, China, 2011.

[62] China's National Bureau of Statistics, Fujian Statistical Yearbook 2010, China Statistics Press, Beijing, China, 2011. 

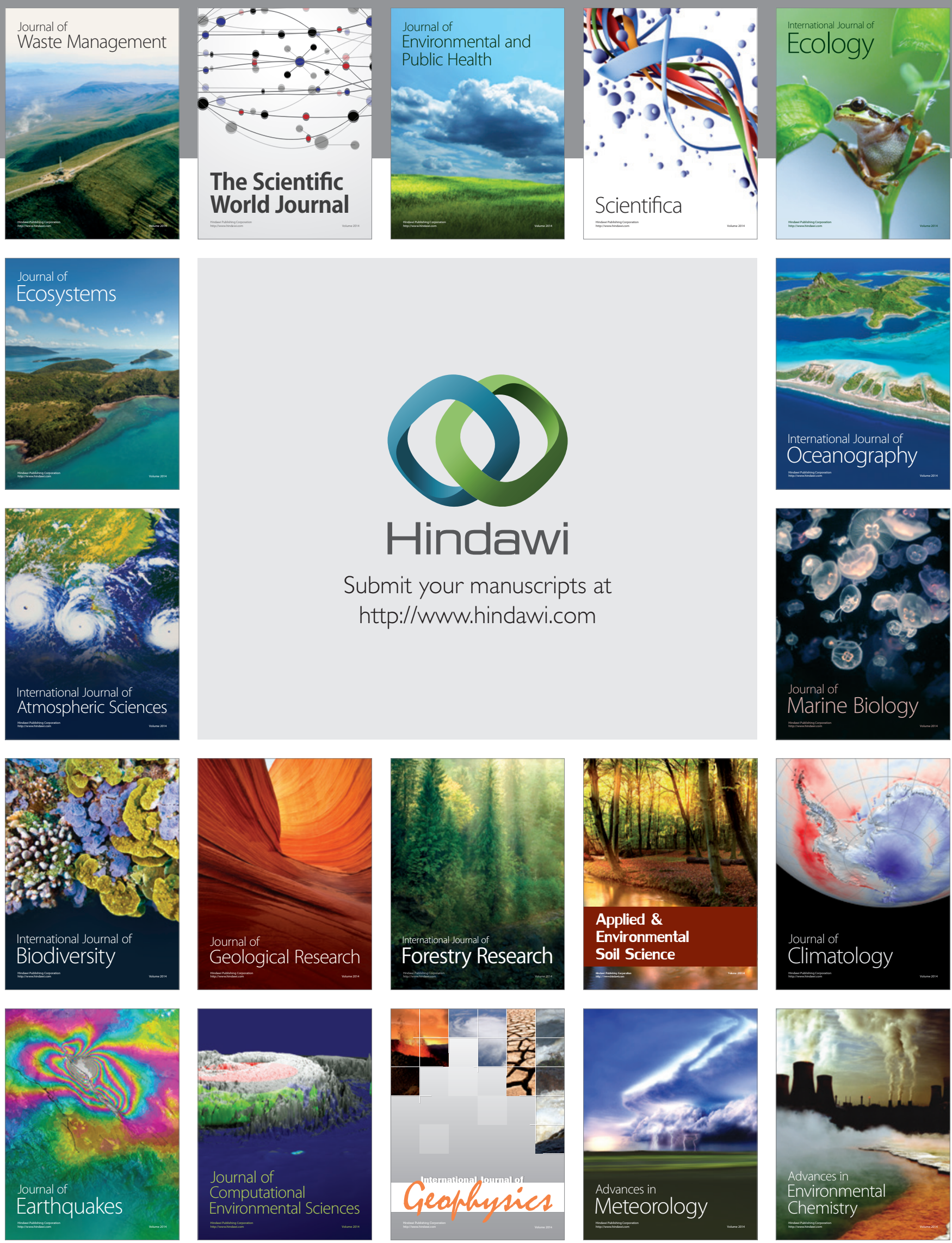